\title{
EU-Iran Relations in the Post-JCPOA Period: Selected Political Aspects
}

\begin{abstract}
After the 1979 revolution, Europe's policy of engaging Iran differed from the American approach. The circumstances changed in 2002, when the international community learnt about the undeclared nuclear sites at Arak and Natanz, as well as the scale of the Iranian nuclear program. The situation became even more complex when Mahmoud Ahmadinejad came to power in 2005. From that moment on, the European Union has changed its attitude toward Iran. Moreover, after Mahmoud Ahmadinejad had been re-elected under controversial circumstances in 2009, the EU intensified sanctions against Iran, even in such cases when they were divergent from member states' interests.

Bilateral affairs began to normalize after the presidential victory of Hassan Rouhani in 2013. Two years later, the EU and other powers from the P5+1 group signed the Joint Comprehensive Plan of Action with Iran. Has the signing of the JCPOA had any impact on Iran-EU political relations as far as non-nuclear related issues are concerned? In order to answer this question, one has to analyze their political relations prior to and after the signing of the deal.

Selected political aspects are taken into consideration, including proliferation related issues, attitudes toward changes in the Arab world, regional conflicts, especially in Syria and Yemen, combating the so-called Islamic State, humanitarian aid to undocumented Afghan refugees, as well as civil liberties and human rights violations in Iran.
\end{abstract}

Key words: the European Union, Iran, Joint Comprehensive Plan of Action, JCPOA, international sanctions

\section{Introduction}

$\mathbf{T}$ he bilateral relations between the Islamic Republic of Iran and the European Union are complex and highly specific. Their analysis has to be based on the fact that Iran is a unitary state, while the EU is a political and economic union of 27 states. As regards the framework for their bilateral relations in the post-Cold War era, one could observe the transformation of the EU foreign policy from a 'Critical Dialogue' to 'Comprehensive Dialogue' at the turn of the century. Undoubtedly, this process made quite an impact on the current state of affairs.

This article is dedicated to the current state of EU-Iran relations after 2015, namely after the signing of the Joint Comprehensive Plan of Action - JCPOA. The agreement was signed in Vienna by representatives of the P5+1 group, namely the five permanent members of the United Nations Security Council and Germany, as well as by negotiators representing Iran and the European Union. On the basis of this deal, Iran agreed for the reduction of all installed centrifuges by two-thirds and its stockpile of low-enriched uranium, as well as the reintroduction of the EU and US sanctions unless it meets the requirements and the redesign of the Arak heavy-water reactor so that it cannot produce weapons grade plutonium (Kaya, Sartepe, 2015, p. 5). 
Has the signing of the JCPOA had any impact on Iran-EU political relations as far as non-nuclear related issues are concerned? In order to answer this question one has to compare situations prior to and following the signing of the JCPOA. The chosen period covers Mahmoud Ahmadinejad and Hassan Rouhani's presidencies, namely between 2005 and 2017. Selected political aspects were taken into consideration, including nuclear proliferation related issues, attitudes toward changes in the Arab world, regional conflicts, especially in Syria and Yemen, combating the so-called Islamic State, humanitarian aid to undocumented Afghan refugees, as well as civil liberties and human rights violations in Iran. The analysis is based on primary sources, monographs, academic articles, and reports.

\section{The Framework for Bilateral Cooperation: From 'Critical Dialogue' to 'Comprehensive Dialogue'}

The end of the Cold War and the death of Ayatollah Khomeini determined the position of Iran on the international stage in the 1990s. Internal as well as external changes opened the door to the significant revision of Iranian foreign policy objectives. Shireen T. Hunter points out that, since the establishment of the European Union, its relations with Iran "have been mostly conducted within the EU framework and in the context of, first, the critical dialogue and, later, the comprehensive dialogue" (Hunter, 2010, p. 84).

Soon after its establishment in 1992, the EU introduced critical dialogue, namely a common and new approach to Iran. The main aim of the critical dialogue was to acknowledge American concerns in principle, and at the same time improve relations with Iran. Representatives of EU institutions assumed that engagement would encourage Iran to moderate its policies. In practice, however, such an approach appeared to be more effective in case of trade and economic cooperation rather than in the case of Iran's policies on the Middle East peace process, or on human rights violations (Moshaver, 2003, p. 294). The way to comprehensive dialogue between the EU and Iran was opened when Mohammad Khatami became the Iranian president in 1997. The new president tried to improve relations with European partners. This rapprochement was necessary after the assassinations in Paris and Berlin. ${ }^{1}$ The European Union tried to strengthen Khatami and the moderate reformists around him in return (Rieffer-Flanagan, 2013, p. 155).

The US-led war in Iraq, and the disagreement between some EU member states, especially Germany and France, and the United States created a new situation. According to Anoushiravan Ehteshami, "both Iran and the European Union had much to gain from putting the EU's constructive engagement dialogue with Tehran. Iran could try to engage Europe against the United States; the European Union could claim to be taking direct and effective action to bring Iran into line on the nuclear and other issues without the need or threat of use of force" (Ehteshami, 2014, p. 278). Yet everything changed when

${ }^{1}$ EU-Iran relations became strained after the killings of Iranian exiles in France and Germany. The former Prime Minister of Iran, Shapour Bakhtiar was killed in Paris in August 1991 and a group of Kurdish dissidents in Berlin in September 1992. The court ruling of 1997, blaming the Iranian intelligence for the attack at the Mykonos Greek restaurant in Berlin, resulted in a political crisis between Iran and the EU. 
the international community learnt about the scale of the Iranian nuclear project. In June 2003, the IAEA Board of Governors expressed concern about Iran's failures and lack of cooperation with the agency. The actions taken by the Iranian government attracted a lot of criticism, especially as some experts feared that Iran might have acquired nuclear weapons. The situation became even more complex when Mahmoud Ahmadinejad was elected president of the Islamic Republic of Iran in 2005.

\section{EU-Iran Relations in the Pre-JCPOA Period}

One of the most important factors shaping EU-Iran relations at the very beginning of the $21^{\text {st }}$ century was the Iranian nuclear program. This project resulted in tense relations and led to international sanctions. The European Union's representatives became very concerned. Some EU member states decided to prevent Iran from acquiring nuclear weapons. Following the IAEA Board of Governors statement, France, Germany and the UK decided to initiate a joint action. Their ministers of foreign affairs formed a diplomatic group, which is often referred to as EU-3 (Iran's Strategic, 2005, p. 17-18). This group attempted to limit the Iranian nuclear program. It was enlarged in 2006, when China, Russia, and the United States joined EU-3. Then some politicians and journalists coined a new name, namely EU3+3. Most analysts, however, used another name - the $\mathrm{P} 5+1$ group.

The situation became even more complex when Mahmoud Ahmadinejad won the presidential elections in 2005. His predecessor, Khatami, was perceived as a reformist, and a leader that could have changed Iran's relations with the West. The victory of Ahmadinejad, however, shattered that prospect. Furthermore, the European engagement with Iran in order to mitigate its radical behavior seemed to have failed as well (Drenou, 2008, p. 83). According to Walter Posch, Ahmadinejad's "inflammatory remarks on Israel and denial of the Holocaust, which are particularly sensitive issues in Europe, poisoned the diplomatic climate. They also destroyed the inroads achieved during the Khatami presidency" (Posch, 2010, p. 191).

Ahmadinejad's harsh rhetoric and anti-Western comments resulted in a loss of confidence that Iran's intentions were to use its nuclear program exclusively for peaceful purposes. As Shahram Akbarzadeh and Dara Conduit put it, "President Ahmadinejad's provocative style had brought Iran to the brink of catastrophe. On more than one occasion, Washington or Tel Aviv threatened military intervention, while economic sanctions and fiscal mismanagement wreaked havoc on the oil-rich Iranian economy" (Akbarzadeh, Conduit, 2016, p. 2). EU member states, as well as EU institutions, were also alarmed at reports informing about the progress of the work of Iranian scientists. Because there were increasing doubts as to the peaceful nature of the nuclear program, the United Kingdom and France proposed to implement a full embargo on oil at the end of 2011.

EU-Iran relations further deteriorated when the European Union imposed economic sanctions on Iran in 2012 (Council regulation, 2012). The EU banned member states from importing oil, and introduced new financial sanctions which in practice excluded Iran from the global financial system (Juneau, 2013, p. 28). This way, European institutions intended to exert pressure on the Iranian government and force it to abandon its 
nuclear program, or at least agree to more detailed controls. The only hesitation centered on the lack of sufficient oil supplies. Yet the situation changed when Saudi Arabia declared that it would seek to make up the difference, and this statement triggered the European action (Cordesman, Gold, Coughlin-Schulte, 2014, p. 45). Maaike Warnaar underlines the fact that as Western pressure on Iran persisted, relations with important economic partners were made increasingly difficult and Iranians felt the effect of international sanctions (Warnaar, 2013, p. 134-135).

Yet the problem was that even when the EU introduced those extensive sanctions, its approach toward Iran was still softer than the American one. According to Shahriar Sabet-Saeidi, the European Union always takes a softer position towards Iran than the United States on controversial issues. The main reason is Europe needs Iran's help to secure its interests in Iraq and Afghanistan, as well as in the Middle East (Sabet-Saeidi, 2011, p. 65). And this constructive European attitude resulted in, for example, the first diplomatic success in Geneva in 2013.

Another factor was related to the political changes in the Arab world after 2011. This process represented a serious challenge to the European Union and Iran. Both sides welcomed the political changes in the Middle East region after 2011, yet for different reasons. Europeans tried to respond to these changes by protecting their interests in the framework of the well-established Euro-Mediterranean relations and the European Neighborhood Policy. For this reason the first EU reactions did not support progressive changes in the region (Bicchi, 2014, p. 435; Fioramonti, 2012, p. 29). According to Tobias Schumacher, this strategy endangered trust in the EU as a crisis manager and a potential promoter of democracy. The EU's 'informational diffusion' was thus replaced by 'informational confusion'. European indecision was characterized by "the predominance of uncoordinated intergovernmental action over collective efforts which continued to generate friction" (Schumacher, 2015, p. 563).

At the same time, Iran aimed at strengthening its regional role. In the opinion of Morgane Colleau, "Iran's history of great civilization and its cultural legacy have produced long-standing national perceptions of a legitimate and key role to play in the regional environment" (Colleau, 2017, p. 89). The main problem was, however, a dual foreign policy. While Supreme Leader Ali Khamanei perceived changes in the Arab world as being inspired by the Iranian revolution, President Mahmoud Ahmadinejad was convinced that the so-called Arab Spring derived from an American-Israeli conspiracy. Its main aim was to create divisions within the Islamic world. According to Amir Mohammad HajiYousefi, "the consequence of the first perception is the widespread support of people's political struggles in the region, establishment and development of relations at a societal level, whereas the second perception has resulted in a strengthening of ties between Tehran and the states in the region so as to prevent the instability and division of these states" (Haji-Yousefi, 2012, p. 23). From the EU's point of view, both perceptions were unacceptable.

Despite these tensions and political differences, the EU continued to fund humanitarian projects targeting Afghan refugees in Iran. This support was initiated in 1997. Its primary aim is to help refugees, while the secondary aim is to prevent Afghan refugees from making the move to Europe. The EU offers assistance to people who seek safety from pervasive insecurity, because the Iranian government has so far deported thousands of 
Afghan refugees. There were more than 200,000 Afghans in 2007 alone (Stanzel, 2016). Obviously, the more projects financed on the spot, the bigger chance that they would stay in Iran instead of moving onward to the EU.

In the pre-JCPOA period the European Union was very critical of respect for civil liberties and human rights in Iran. The best example was the EU's reaction to the controversial re-election of Mahmoud Ahmadinejad and the oppression of participants in the Green Movement's protests in 2009. Two years later the EU adopted restrictive measures related to human rights violations in Iran. The most important measures were related to the asset freeze and visa bans for individuals who from the EU's point of view were responsible for such violations. In addition, European countries agreed that they will not allow any EU company to export to Iran any "equipment which might be used for internal repression and equipment for monitoring telecommunications" (Measures responding, 2017).

The best opportunity for improving bilateral relations appeared when Hassan Rouhani won the presidential elections and came to power in 2013. Javad Zarif, the newly appointed minister of foreign affairs, openly said that the president intended, among others, to improve relations with the West, including European partners. In his article entitled What Iran Really Wants: Iranian Foreign Policy in the Rouhani Era, Javad Zarif declared: "Iran will also engage with European countries and other Western states with the goal of reinvigorating and further expanding relations. This normalization process must be based on the principles of mutual respect and mutual interest, and it must address issues of legitimate concern to both sides" (Zarif, 2014, p. 10).

President Rouhani and his aides resumed negotiations and gave new impetus to the talks with the P5+1 group. The first step towards normalization of bilateral relations took place with formal adoption of the Joint Plan of Action in Geneva in 2013 (Joint, 2013). The JPA was in line with Iranian interests, especially as far as EU-Iran bilateral trade was concerned. Although the EU decided not to lift its sanctions imposed on Iran in 2012, trade turnover increased by 68 percent in 2014 alone (Entessar, Afrasiabi, 2015, p. 169).

Finally, the new approach of Iranian diplomacy resulted in the signing of the Joint Comprehensive Plan of Action, which took place in Vienna on July 14, 2015. ${ }^{2}$ In comparison with the previous ten years, the deal was a political milestone in Iran's relations with the West in general, and in particular with the EU.

\section{The Post-JCPOA Period: Political Aspects}

Within the framework of the JCPOA, Iran committed to:

- reduce its stockpile of low-enriched uranium by 98 percent;

- put more than two thirds of its centrifuges in storage;

- modernize the Arak heavy water reactor;

- stop enriching uranium at the Fordow facility for 15 years;

- agree to multilayered supervision of its entire nuclear infrastructure by the IAEA (Joint, 2015).

${ }^{2}$ For more about the negotiation process see: Parsi, Trita (2017), Losing an Enemy: Obama, Iran, and the Triumph of Diplomacy, Yale University Press, New Haven and London. 
Iran complied with the JCPOA obligations, and therefore the implementation of sanctions relief began faster than expected. Although there were some problems and concerns related to the ballistic missile program, the European Union and its member states waited for the definitive opinion of the International Atomic Energy Agency (Axworthy, 2017, p. 173). On January 16, 2016, the IAEA announced that Iran had met the fundamental conditions envisaged in the JCPOA (Verification, 2016). On January 22, the Council decided to lift the nuclear-related sanctions (Council Implementing, 2016). That day is often referred to as 'Implementation Day'. Some restrictions remained in place, for instance, the arms embargo and missile technology sanctions. In addition, some persons and entities remained subject to the asset freeze and visa ban (Information Note, 2016).

There are three main objectives of EU-Iran relations in the post-JCPOA period, namely:

- the full implementation of the main provisions of the accord;

- increased cooperation in areas of mutual interest;

- promotion of regional peace, security, stability, and peaceful settlement of regional conflicts (Iran and the EU, 2016).

The JCPOA opened the door to political dialogue as well as new investments and a further increase in trade turnover. On the basis of the joint statement of the High Representative of the European Union for Foreign Affairs and Security Policy Federica Mogherini and Javad Zarif of April 2016, the EU is likely to improve banking cooperation, plan some investments under the umbrella of the European Investment Bank, cooperate in a variety of sectors, and build on expertise in the field of SMEs. The EU also supports Iran's membership of the World Trade Organization, and its further integration into the world economy.

The post-JCPOA situation, nevertheless, has become much more complex and unpredictable since Donald Trump won the US presidential elections in November 2016. Even as a candidate, he often criticized the Obama administration for the deal with Iran. For instance, during a speech addressed to the American Israel Public Affairs Committee - AIPAC of March 2016, Donald Trump said as follows: "My number-one priority is to dismantle the disastrous deal with Iran. And let me tell you, this deal is catastrophic for America, for Israel and for the whole of the Middle East. The problem here is fundamental. We've rewarded the world's leading state sponsor of terror with $\$ 150$ billion, and we received absolutely nothing in return. They can keep the terms and still get the bomb by simply running out the clock. And of course, they'll keep the billions and billions of dollars that we so stupidly and foolishly gave them" (Trump, 2016).

European institutions do not see any need for an introduction of new non-nuclear sanctions, as suggested by some members of President Donald Trump's entourage. Nevertheless, while the European powers do not support new sanctions against Iran, they are closely watching Iran's role in the region. Regional order, peace and stability in the Middle East remain significant, especially to key member states like France, Italy, and Germany. If Iran or its proxies cross any red line; for instance, any direct engagement in the Yemeni conflict, or any hostile actions against Arab states in the Persian Gulf, Brussels may be open to the Trump administration's suggestions. Yet everything indicates that the EU would rather focus on cooperating with Iran, especially on such issues as trade, combating terrorism, and the refugee crisis. 
The European Union has not reacted to any of the warnings coming from President Donald Trump, at least for the moment. For instance, on January 12, 2018 the US president declared: "Today, I am waiving the application of certain nuclear sanctions, but only in order to secure our European allies' agreement to fix the terrible flaws of the Iran nuclear deal. This is the last chance. In the absence of such an agreement, the United States will not again waive sanctions in order to stay in the Iran nuclear deal. And if at any time I judge that such an agreement is not within reach, I will withdraw from the deal immediately" (Trump, 2016). He presented his opinion the day after an EU/E3 and Iran meeting on January 11, 2018, when Federica Mogherini had made the following statement: "While we have expressed concerns related to other issues, such as development of ballistic missiles and increasing tensions in the region, these issues are outside the scope of the nuclear agreement and are and will be addressed in the relevant formats and fora. The deal is working; it is delivering on its main goal, which means keeping the Iranian nuclear program in check and under close surveillance. The European Union remains committed to support the full and effective implementation of the agreement, including to make sure that the lifting of nuclear related sanctions has a positive impact on trade and economic relations with Iran, including benefits for the Iranian people" (Mogherini, 2018). Her statement, no doubt, is underpinned by the facts. Since the JCPOA was finalized, a large number of European delegations have paid official visits to Tehran. What is more, European countries support Iran's ambitions to accede to the World Trade Organization, although the United States opposes this initiative (Katzman, 2017, p. 51), and EU imports from Iran increased 334.8 percent and exports by 27.8 percent in 2016 alone (Iran, 2017).

As regards the process of political changes in the Arab world after 2011, Iran's position, as well as political and military involvement in the ongoing Syrian conflict is in line neither with the EU's expectations, nor the interests of its member states. While the Iranian government still supports Syrian President Bashar al-Assad, the European Union demands his surrender and will not accept any political role for him in post-war Syria.

The same applies to the ongoing conflict in Yemen. In this particular case, the conflict gained momentum in spring 2015, when the Saudi Arabian-led intervention began, so it is impossible to compare the EU and Iran's positions prior to and after the signing of JCPOA. Nevertheless, one can notice some important differences as far as their current stances are concerned.

The rise of the so-called Islamic State brought Iran and the European Union's shared interests into sharper focus. After 2014, it became clear that it would be almost impossible to defeat this terrorist organization without Iranian ground forces and Iran backed militias, especially in Iraq. Supreme Leader Ali Khamenei condemned the terrorist attacks in France and addressed young people in Europe and the United States in November 2015. This way Iran confirmed its anti-IS stance and the existence of convergent interests in the Middle East and beyond the region. Yet, at the same time, the supreme leader criticized the West: "Alongside this direct support, the palpable and known supporters of Takfiri terrorism, despite having the most primitive political establishments, have always been among the allies of the West, and that is while the most progressive and the clearest thoughts born out of dynamic democracies in the region have been ruthlessly suppressed. The West's double-standards vis-à-vis the movement of awakening in the Muslim world is a telling example of contradiction in the Western policies" (Khamenei, 2015). 
In the post-JCPOA period the European Union continues to give humanitarian assistance to Iran. In 2017, the European Commission allocated 10 million euro to Afghan refugees, especially to integrate their children into the Iranian education system (European, 2018). Another 5 million euro will be transferred to Iran in 2018 (Humanitarian Aid, 2018).

Although the EU decided to lift nuclear-related sanctions against Iran after the signing of the JCPOA, it still extends sanctions responding to serious human rights violations. On April 11, 2017, the Council of the EU decided to extend the measures put in place in 2011 until April 13, 2018. At present these sanctions include a travel ban and an asset freeze against 82 people, as well as a ban on exports of equipment which might be used for internal repression (Council extends, 2017). Despite this, however, some analysts and politicians criticized the EU's weak response to the latest wave of antigovernment protests in January 2018 (Snell, 2018; Erlanger, 2018; Vaez, 2018). Did the EU compromise on them in order to avoid bilateral tensions with Iran? For the moment everything indicates that the European Union adopted a strategy of 'wait and see'. Although EU institutions are monitoring the current developments and extending sanctions related to human rights violations, they do not intend to provoke the Iranian side with no apparent reason. Of course, European states may seek other reasons to put pressure on Iran. For instance, in January 2018, German diplomacy considered the introduction of new sanctions in order to support the US administration's point of view and in response to the Iranian missile program as well as meddling in the ongoing conflicts in the Middle East region (European countries, 2018). Yet, at least for the moment, everything indicates that the EU is satisfied with provisions of the JCPOA deal, the process of its implementation as well as the first tangible results.

\section{Conclusion}

The signing and implementation of the JCPOA improved political relations between the European Union and Iran. It seems that the deal increased mutual confidence not only in case of nuclear-related aspects, but also in case of non-nuclear issues. Although there are still some divergent aspects like their attitudes toward changes in the Arab world or human rights violations in Iran, one can say that the signing of the JCPOA has had a moderate impact on EU-Iran political relations since 2015. Both the EU and Iran have developed bilateral cooperation on diplomatic contacts, the EU's assistance to undocumented Afghan refugees, further implementation of the JCPOA's provisions, Iran's membership of the WTO, and trade.

Nothing indicates, at least for the moment, that the EU might change its general approach towards Iran. Europeans do not intend to renegotiate or amend the deal, as suggested by US President Donald Trump. Yet the situation might change if Iran crossed any red line, for instance, in the case of the ballistic missiles program, serious human rights violations or engagement in any new conflict in the Middle East. The initiative of German diplomacy of January 2018 is the best proof that Iranians should not be absolutely certain that the EU will never change its position on the JCPOA. For the time being, trade and potential investments seem to be driving bilateral relations, but Europeans 
may change their mind once their companies begin losing tenders or contracts. President Rouhani and Javad Zarif seem to understand that, and that is the reason why they are paying attention to constructive and fruitful relations with the EU. They also know that Iran stands to gain, as long as there is a difference of positions between the EU and the United States.

\section{Bibliography}

Akbarzadeh S., Conduit D. (2016), Rouhani's First Two Years in Office, in: Iran in the World: President Rouhani's Foreign Policy, eds. S. Akbarzadeh, D. Conduit, Palgrave Macmillan, Basingstoke.

Axworthy M. (2017), Iran: What Everyone Needs to Know, Oxford University Press, New York.

Bicchi F. (2014), Europe and the Arab Uprisings: The Irrelevant Power?, in: The New Middle East: Protest and Revolution in the Arab World, ed. F. A. Gerges, Cambridge University Press, New York.

Colleau M. (2017), The Kaleidoscope of Iran's Foreign Policy in the Context of Profound Regional Upheavals, in: Reassessing Order and Disorder in the Middle East: Regional Imbalance or Disintegration?, ed. R. Mason, Rowman \& Littlefield, Lanham.

Cordesman A. H., Gold B., Coughlin-Schulte C. (2014), Iran - Sanctions, Energy, Arms Control, and Regime Change, Center for Strategic \& International Studies, Washington D.C.

Council Extends by One Year Sanctions Responding to Serious Human Rights Violation (2017), The Council of the European Union, http://www.consilium.europa.eu/en/press/press-releases/2017/04/11/iran-sanctions/, 18.02.2018.

Council Implementing Decision (CFSP) 2016/78 of 22 January 2016 implementing Decision 2010/413/ CFSP concerning restrictive measures against Iran, "Official Journal of the European Union", L 16, 23.01.2016.

Council Regulation No 267/2012 of 23 March 2012 concerning restrictive measures against Iran and repealing Regulation No 961/2010, “Official Journal of the European Union”, L 88, 24.03.2012.

Drenou A. Th. (2008), Iran: Caught Between European Union - United States Rivalry?, in: Iran's Foreign Policy From Khatami to Ahmadinejad, eds. A. Ehteshami, M. Zweiri, Ithaca Press, Reading.

Ehteshami A. (2014), The Foreign Policy of Iran, in: The Foreign Policies of Middle East States, eds. R. Hinnebusch, A. Ehteshami, Lynne Rienner Publishers, Boulder.

Entessar N., Afrasiabi K. L. (2015), Iran Nuclear Negotiations: Accord and Détente Since the Geneva Agreement of 2013, Rowman \& Littlefield, Lanham.

Erlanger S. (2018), Europe Resists Trump's Call for Tougher Measures on Iran, “The New York Times", 3.01.2018.

European Civil Protection and Humanitarian Aid Operations (2018), European Commission, http:// ec.europa.eu/echo/where/asia-and-pacific/iran_en, 6.02.2018.

European Countries Ready to Impose New Sanctions on Iran in Response to US Pressure - report (2018), "The National", https://www.thenational.ae/world/europe/european-countries-readyto-impose-new-sanctions-on-iran-in-response-to-us-pressure-report-1.697146, 21.01.2018.

Fioramonti L. (2012), Promoting Human Rights and Democracy: A New Paradigm for the European Union, in: The European Union and the Arab Spring: Promoting Democracy and Human Rights in the Middle East, ed. J. Peters, Lexington Books, Lanham.

Haji-Yousefi A. M. (2012), Iran and the 2011 Arab Revolutions: Perceptions and Actions, "Discourse: An Iranian Quarterly", vol. 10, no. 1-2.

Humanitarian Aid: 37.5 million euro for Afghanistan, Pakistan and Iran (2018), The European Commission, http://europa.eu/rapid/press-release_IP-18-384_en.htm, 30.01.2018. 
Hunter S. T. (2010), Iran's Foreign Policy in the Post-Soviet Era: Resisting the New International Order, Praeger, Santa Barbara.

Information Note on EU Sanctions to be Lifted Under the Joint Comprehensive Plan of Action (2016), European External Action Service, http://eeas.europa.eu/archives/docs/top_stories/pdf/iran_ implementation/information_note_eu_sanctions_jcpoa_en.pdf, 23.01.2016.

Iran (2018), European Commission, http://ec.europa.eu/trade/policy/countries-and-regions/countries/ iran/, 18.02.2018.

Iran and the EU (2016), European External Action Service, https://eeas.europa.eu/delegations/ iran/2281/iran-and-eu_en, 22.10.2016.

Iran's Strategic Weapons Programmes: A Net Assessment (2005), The International Institute for Strategic Studies, London.

Joint Comprehensive Plan of Action (2015), U.S. Department of State, https://www.state.gov/e/eb/tfs/ spi/iran/jcpoa/, 14.07.2015.

Joint Plan of Action (2013), Geneva, 24.11.2013.

Juneau T. (2013), Iran: rising but unsustainable power, unfulfilled potential, in: Iran Foreign Policy since 2001: Alone in the world, eds. T. Juneau, S. Razavi, Routledge, New York.

Katzman K. (2017), Iran's Foreign and Defense Policies, U.S. Congressional Research Service, R44017.

Kaya S., Sartepe Z. (2015), Contentious Politics in Iran: Factions, Foreign Policy and the Nuclear Deal, “Alternatives: Turkish Journal of International Relations", vol. 14, no. 3.

Khamenei A. (2015), Ayatollah Khamenei Urges Western Youth to Facilitate Correct Interaction with Muslims, http://www.leader.ir/en/content/13964/Ayatollah-Khamenei-issues-a-second-letterto-the-youth-in-Western-countries, 30.11.2015.

Measures responding to serious human rights violations: Iran (2017), The European Council, http:// www.consilium.europa.eu/en/policies/sanctions/iran/, 18.02.2018.

Mogherini F. (2018), Iran: EU committed to full implementation of nuclear deal, EEAS, Taskforce Iran, https:/eeas.europa.eu/delegations/iran/38156/iran-eu-committed-full-implementation-nucleardeal_en, 11.01.2018.

Moshaver Z. (2003), Revolution, Theocractic Leadership and Iran's Foreign Policy: Implications for Iran-EU Relations, "The Review of International Affairs", vol. 3, no. 2.

Posch W. (2010), Iran and the European Union, in: The Iran Primer: Power, Politics, and U.S. Policy, ed. R. Wright, United States Institute of Peace Press, Washington D.C.

Rieffer-Flanagan B. A. (2013), Evolving Iran: An Introduction to Politics and Problems in the Islamic Republic, Georgetown University Press, Washington D.C.

Sabet-Saeidi S. (2011), Iranian-European Relations: A Strategic Partnership?, in: Iran's Foreign Policy: From Khatami to Ahmadinejad, eds. A. Ehteshami, M. Zweiri, Ithaca Press, Reading.

Schumacher T. (2015), The European Union and Democracy Promotion: Readjusting to the Arab Spring, in: Routledge Handbook of the Arab Spring: Rethinking Democratization, ed. L. Sadiki, Routledge, New York.

Snell J. (2018), European Leaders' Response to Iran Protests is Weak and Disingenuous, The New Arab, https://www.alaraby.co.uk/english/Comment/2018/1/2/EU-response-to-Iran-protests-isweak-and-disingenuous, 2.01.2018.

Stanzel A. (2016), Eternally Displaced: Afghanistan's Refugee Crisis and What It Means for Europe, European Council on Foreign Relations, Policy Brief ECFR 170, May.

Trump D. (2016), Speech to AIPAC, http://time.com/4267058/donald-trump-aipac-speech-transcript/, 21.03.2016.

Trump D. (2018), Statement by the President on the Iran Nuclear Deal, The White House, https://www. whitehouse.gov/briefings-statements/statement-president-iran-nuclear-deal/, 12.01.2018. 
Warnaar M. (2013), Iranian Foreign Policy During Ahmadinejad, Palgrave Macmillan, New York.

Vaez A. (2018), Can Europe Save the Iran Deal? Time for It to Consider a Plan B, "Foreign Affairs", https://www.foreignaffairs.com/articles/europe/2018-01-16/can-europe-save-irandeal?cid=int-fls\&pgtype=hpg, 16.01.2018.

Verification and Monitoring in the Islamic Republic of Iran in Light of United Nations Security Council Resolution 2231/2015 (2016), IAEA Board of Governors, GOV/INF/2016/1, 16.01.2016.

Zarif M. J. (2014), What Iran Really Wants: Iranian Foreign Policy in the Rouhani Era, "Foreign Affairs", May/June.

\section{Relacje Unii Europejskiej z Iranem po zawarciu porozumienia nuklearnego (JCPOA). Wybrane aspekty polityczne}

\section{Streszczenie}

Po 1979 roku podejście państw europejskich w stosunku do Iranu różniło się znacząco od polityki prowadzonej przez Stany Zjednoczone. Okoliczności uległy zmianie, gdy w 2002 roku społeczność międzynarodowa dowiedziała się o istnieniu dwóch tajnych ośrodków badawczych w Araku i Natanzie, w których Irańczycy prowadzili badania nad energią atomową. Sytuacja stała się jeszcze bardziej złożona, gdy w 2005 roku urząd prezydenta Iranu objął Mahmud Ahmadineżad. Wówczas Unia Europejska wyraźnie zaostrzyła swoje stanowisko w sprawie irańskiego programu atomowego. Co więcej, po kontrowersyjnej wygranej Ahmadineżada i wyborze na drugą kadencję, Unia wprowadziła sankcje nawet $\mathrm{w}$ takich przypadkach, w których były one rozbieżne z interesami poszczególnych państw członkowskich.

Stosunki dwustronne uległy normalizacji dopiero po objęciu prezydentury przez Hasana Rouhaniego. Zainicjowane przez niego nowe podejście w ramach prowadzonej polityki zagranicznej umożliwiło podpisanie przez Iran porozumienia nuklearnego (JCPOA - the Joint Comprehensive Plan of Action) z grupą P5+1 w 2015 roku. Główny problem badawczy brzmi: czy i w jaki sposób podpisanie porozumienia wpłynęło na stan stosunków politycznych pomiędzy Unią Europejską a Iranem? Aby odpowiedzieć na powyższe pytanie, analizie poddano stanowiska stron w odniesieniu do wybranych kwestii politycznych przed i po podpisaniu porozumienia.

Wśród wybranych zagadnień, poddanych analizie w niniejszym artykule, znalazły się: kwestia proliferacji, stosunku do zmian politycznych w świecie arabskim, zwłaszcza w Syrii i Jemenie, zwalczanie organizacji tzw. Państwa Islamskiego, pomoc humanitarna dla afgańskich uchodźców w Iranie, a także poszanowanie praw wolności obywatelskich w Iranie.

Słowa kluczowe: Unia Europejska, Iran, porozumienie nuklearne z Iranem, JCPOA, sankcje międzynarodowe 
